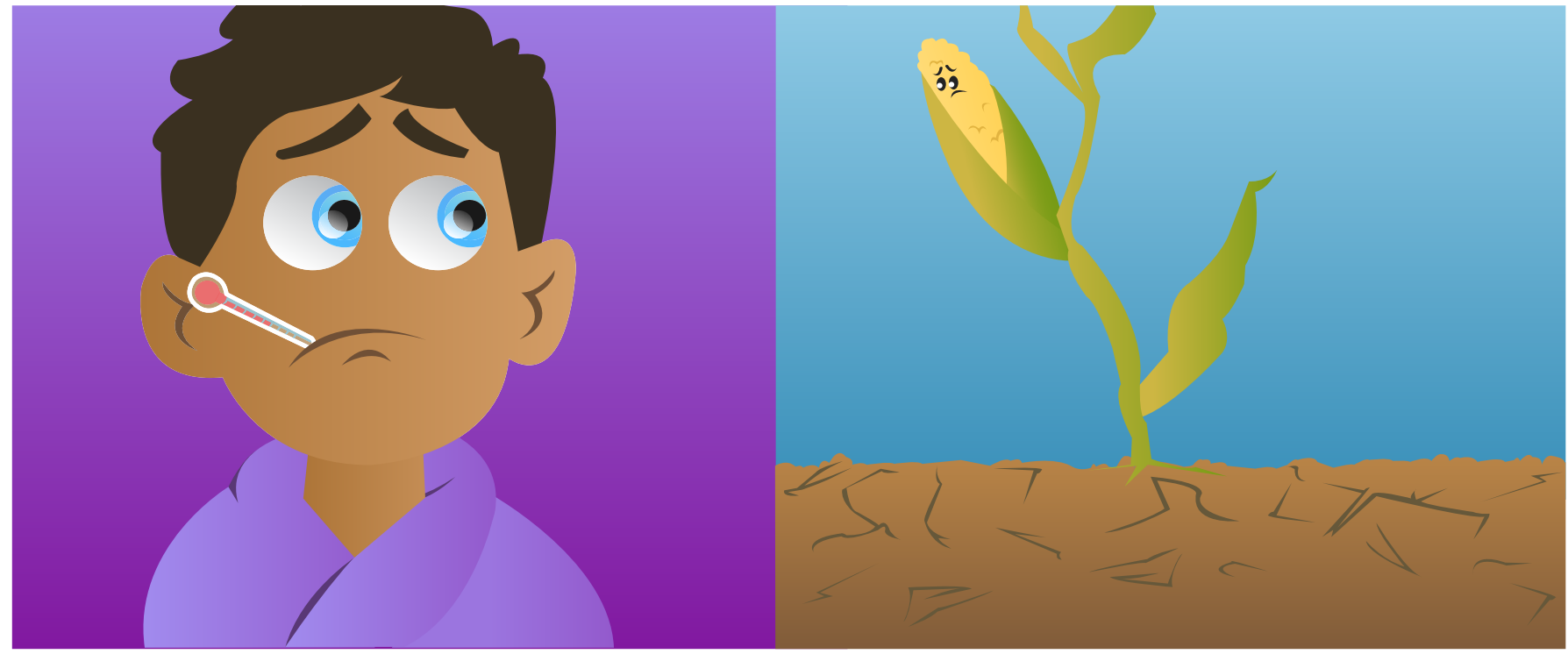

\title{
DOES STRESS CHANGE WHO WE ARE?
}

\section{Katherine McKissick ${ }^{1}$ and Ann E. Stapleton ${ }^{2 *}$}

${ }^{1}$ Beatrice the Biologist, Inc., Los Angeles, CA, United States, ${ }^{2}$ Department of Biology and Marine Biology, University of North Carolina Wilmington, Wilmington, NC, United States

\section{REVIEWED BY:}

SLAUSON MIDDLE SCHOOL 11-12 YEARS OLD
All living things deal with stress. For you, that might be having a cold in addition to not getting enough sleep. For a plant, it is stressful to live through a drought. It turns out that stress is more than a passing annoyance. It can actually change who we are. Sometimes stress can affect our DNA, the instruction manual for building a living thing. Stress does not rewrite the letters in the DNA instruction manual, but it can change which chapters are used, and which ones are skipped over. Researchers are using corn plants to better understand how different kinds of stress can change how tall the plants grow. Understanding how DNA and the environment work together can not only help us grow bigger, better corn but it can also help us understand other organisms too, including ourselves.

\section{WHAT MAKES YOU ... YOU?}

Have you ever wondered if you'd be different if you had grown up in another place or time? Would you be the same person you are now? Our experiences play a big part in our identities. Your family, your home, your school, and all the things you have done have shaped who you are today. But how much? If you were born in ancient Egypt, medieval France, or modern-day Mongolia, you might be the same as you are now, or you might be completely different. 


\section{DNA}

The twisted laddershaped molecule found in all living things that serves as an instruction manual for building and maintaining an organism.

\section{EXPRESS}

The act of using DNA to make a gene product such as a protein. The DNA in living things has many genes, which are used at different times or places in the organism.

\section{GENOTYPE}

An organism's entire DNA instruction manual, which is the same in identical twins but differs in non-identical individuals.

\section{GENE}

A particular section of DNA - a chapter in the DNA instruction manualthat contains instructions for making a gene product.

\section{GENE PRODUCT}

A molecule that is made according to the instructions of a gene. Gene products can make proteins immediately, or gene products can be controlling RNAs that affect the way other proteins work.

\section{PHENOTYPE}

The result of an organism's expressed genotype, which are all the observable characteristics (traits) of an organism.

The only thing you cannot change about yourself is your DNA, which stands for deoxyribonucleic acid. You got half of your DNA from your mom and the other half from your dad. You cannot change the DNA that you got from them, but the things you do-the experiences you have-can change how that DNA is expressed. But what does that mean?

\section{FROM GENOTYPE TO PHENOTYPE}

Your DNA specifies your genotype, the set of directions for making you who you are. Think of it like an instructional manual for building you. Each chapter is a gene set, a group of related pages that work together. A gene is part of this set of instructions for making one particular product, such as a protein. There are thousands and thousands of genes for making all different kinds of products that your body needs to operate.

Those gene products make up what is called your phenotype, which is what really makes you who you are. It's proteins working together that determine characteristics like your eye color, height, and hair color. Gene products work together to create complex characteristics, like whether or not you like broccoli, are allergic to cats, or enjoy classical music.

The tricky part about this DNA instruction manual is that not all the chapters are used all the time. You may have a chapter for a certain group of genes, but your cells never read it, so the gene products do not get made. That means that a gene is not being expressed.

\section{HOW EXPERIENCES SHAPE US}

It is pretty hard to know if you would be different if you had been born in Peru 100 years ago. That is not easy to test. But one way we can study genotypes and phenotypes is with identical twins, particularly if they were separated at birth. Identical twins share the exact same genotype-their DNA is identical. After growing up apart and having different experiences, identical twins might have different phenotypes. For example, one might have arthritis while the other might not. ${ }^{1}$ So these twins give researchers the opportunity to see how much of the twins' phenotypes were determined by their genotype, and how much could be due to their experiences.

But there is another way to study genotypes and phenotypes, and it is not with humans. It is with plants! (Remember, plants have DNA, too!)

http://learn.genetics.utah.edu/content/epigenetics/twins/. 
MODEL ORGANISM

An organism that scientists use in their experiments, to teach them about other organisms as well. Common model organisms include E. coli bacteria, fruit flies, zebrafish, corn plants, and mice.

\section{VARIABLE}

The part of an experiment that is tested by varying it between trials. For example, if you want to know how water affects plant grown, you could set up an experiment where the variable is the amount of water given each day to different plants.

\section{STRESS}

Aspects of the environment that can have a negative effect on an organism.

It turns out that corn is not just delicious; it is great for science, too. Corn is a good model organism, which means we can use it to learn about things like DNA, and what we learn can from a model organism can apply to other living things too.

In any good experiment, researchers examine one or more variables. A variable is something that is changed from one experiment to the next, to see how it affects the subjects of the experiment. To study genotypes and phenotypes, researchers test how the variables of various life experiences might alter a living thing. Working with plants is great because, well, they do not move around. Researchers can keep track of the plants' "experiences" much more easily, and they are things that are easy to measure. The variables researchers can test with plants could include the type of soil, the amount of water, the level of sunlight, and exposure to pests like insects that chew on the leaves.

Researchers monitored plants that were put under different amount of stress. Just like us, plants can get stressed if they are in a tough situation. For us, we might be stressed out if we are sick or if we do not sleep well. For a plant, living through a drought with too little water can be just as stressful.

Researchers also tested whether plants experiencing several types of stress were affected differently than plants experiencing only one type of stress. If a plant is going through a drought and being attacked by a virus, that can have a different impact on its life than either of those stresses alone [1].

\section{WHEN CORN DOES NOT MIND THE STRESS}

When plants grow up in an environment without much stress, they tend to be relatively similar. For traits, we can easily measure, such as height, it is easy to see. The plants are all roughly the same height.

But when you add stress to the environment, something changes. The plants respond differently. Some plants do just fine, while others do not fare well at all. The variation is what is important. You might expect that, in a drought, all the plants are short or all the plants do not produce as much corn. But that is not the case. Some plants continue to thrive despite the stressful surroundings. And the key to their success lies in their genotype.

In a way, people are like this, too. In an ideal setting, many people grow up happy and healthy. But in a tough situation, some people succeed, while others suffer a great deal.

This graphic ${ }^{2}$ (and Video 1) has two clusters of points representing how tall corn plants can grow. On the left, the points represent how tall corn

2 https://dhbrand.shinyapps.io/young_minds/. 


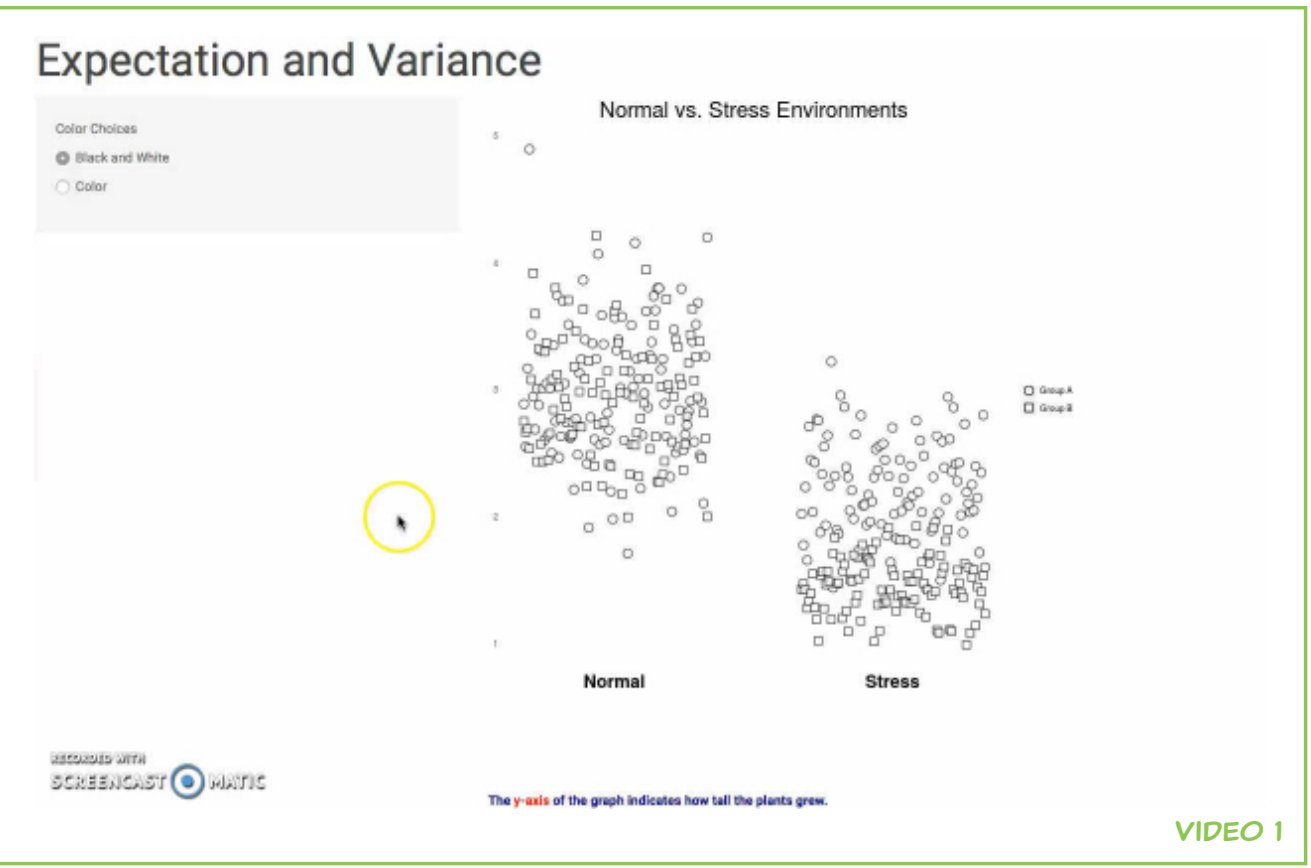

plants might grow in the normal condition, the group without much stress. They are all pretty tall, and there is not a whole lot of variation between the points.

On the right, you will see points that represent how tall corn plants grew in a stressful environment. Some of them are way down at the bottom of the graph; they did not grow tall at all. But look how much variation there is. Some of them-the dots way up at the top-grew as tall as many of the plants in the stress-free environment.

Now let us look at the differences in the genotypes of these plants and how those differences contribute to the height phenotype. For our example, we will have round blue and red square genotypes. Click on the graphic button on the left (see text footnote 2) or continue the movie (Supplemental Video 1 file) to take a look at the colors. The round blue and square red points illustrate what kinds of differences in tallness phenotypes we expect when additional chapters of DNA are used. You can see that, in the normal condition group, the use of the blue chapter and red chapter is not very different, as when either is expressed the plants are pretty tall. In the stressful environment, the plants with the "red" gene chapter expressed are quite a bit shorter. (Hover over the interactive graphic to see the explanations of each part.) In this way, by comparing plants that grow in a stressful environment to plants in the normal environment (in other words, grouping by the stress variable levels), we can find different chapters that we would not be able to notice if we only looked at plants growing in the normal condition. The plants have the DNA for all the chapters' genes (both the red and the blue chapters' genes, in our example graphic), but they differ 
in the use of those chapters; the plants using the red-labeled genes are unable to grow tall in the presence of environmental stress. We know this because we studied how the points on the graph are arranged. The range (or spread) of the points from the top to the bottom of the graph in the black and white view gives us a hint that we should look for use of different genes. We compare the red-labeled points to the blue-labeled points to see which gene expression chapter matters.

If we did not have both the underlying genotype differences that make the blue and red points AND the stress variable in our test corn plots, we would never know that the red-labeled genes make the corn sensitive to stress. Diversity (the wide spread of the points from high to low and the different genotypes-shown as the point colors in the graphic) gives us useful information!

This concept and the methods used to study this are explained in more detail within this scientific review article [2] and more generally in this review article [3]. A recent example of this kind of analysis in human disease may be found in Ref. [4].

\section{MORE TO KNOW}

Like so much in science, this research provides ideas for areas to study further. We can look at more plants, track more of their DNA, and find out more about how it is expressed. Understanding this can lead to all kinds of great knowledge and technology.

In the case of corn, understanding how the environment affects different plants can lead to better farming techniques. Maybe we can get more corn while using less land. That would be great for everyone from the farmer picking the corn to the person eating corn on the cob at a barbecue.

But remember, it is not just about this specific organism. Understanding how to help corn thrive will also help us understand how we can make other organisms be their best in any environment, including people. It is all part of a much bigger picture about what DNA can tell us about ourselves, and how much of our identity lies not in our DNA but in our experiences and what we make of them-in other words, how gene expression affects our own lives.

\section{ACKNOWLEDGMENTS}

The authors thank UNCW students Thomas Billman and Dave Hiltbrand for making the interactive shiny graphic visualization for them. The $\mathrm{R}$ code and explanation of the construction of this simulation and the graphic visualization is available at https://github.com/tbillman/R-Shiny. 


\section{ORIGINAL SOURCE ARTICLE}

Makumburage, G. B., and Stapleton, A. E. 2011. Phenotype uniformity in combinedstress environments has a different genetic architecture than in single-stress treatments. Front. Plant Sci. 2:12. doi:10.3389/fpls.2011.00012

\section{REFERENCES}

1. Makumburage, G. B., and Stapleton, A. E. 2011. Phenotype uniformity in combined-stress environments has a different genetic architecture than in singlestress treatments. Front. Plant Sci. 2:12. doi:10.3389/fpls.2011.00012

2. Landers, D. A., and Stapleton, A. E. 2014. Genetic interactions matter more in less-optimal environments: a focused review of "phenotype uniformity in combinedstress environments has a different genetic architecture than in single-stress treatments" (Makumburage and Stapleton, 2011). Front. Plant Sci. 5:384. doi:10.3389/fpls.2014.00384

3. Geiler-Samerotte, K., Bauer, C., Li, S., Ziv, N., Gresham, D., and Siegal, M. 2013. The details in the distributions: why and how to study phenotypic variability. Curr. Opin. Biotechnol. 24:752-9. doi:10.1016/j.copbio.2013.03.010

4. Soave, D., Corvol, H., Panjwani, N., Gong, J., Li, W., Boëlle, P. Y., et al. 2015. A joint location-scale test improves power to detect associated SNPs, gene sets, and pathways. Am. J. Hum. Genet. 97:125-38. doi:10.1016/j.ajhg.2015.05.015

SUBMITTED: 20 April 2017; ACCEPTED: 30 August 2017;

PUBLISHED ONLINE: 20 September 2017.

EDITED BY: Fulvio D’Acquisto, Queen Mary University of London, United Kingdom

CITATION: McKissick K and Stapleton AE (2017) Does Stress Change Who We Are? Front. Young Minds 5:48. doi:10.3389/frym.2017.00048

CONFLICT OF INTEREST STATEMENT: The authors declare that the research was conducted in the absence of any commercial or financial relationships that could be construed as a potential conflict of interest.

COPYRIGHT (C) 2017 McKissick and Stapleton. This is an open-access article distributed under the terms of the Creative Commons Attribution License (CC BY). The use, distribution or reproduction in other forums is permitted, provided the original author(s) or licensor are credited and that the original publication in this journal is cited, in accordance with accepted academic practice. No use, distribution or reproduction is permitted which does not comply with these terms.

\section{REVIEWED BY}

\section{SLAUSON MIDDLE SCHOOL, $11-12$ YEARS OLD}

We are a class of fun-loving and bright sixth graders in Mrs. Cowhy's science class at Slauson Middle School. Slauson Middle School is committed to the educational success of children from sixth to eighth grade in Ann Arbor, MI, USA. We completed this review with the help of our science mentor, Dr. Pamela Wong. 


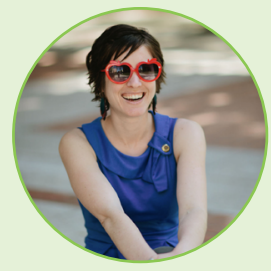

\section{AUTHORS}

\section{KATHERINE MCKISSICK}

Katherine McKissick is the author and illustrator of Beatrice the Biologist. She is a former high school biology teacher who simply loves to talk, write, and read about science. Based in Los Angeles, Katherine McKissick contributes to the science and art blog, Symbiartic, and cohosts the irreverent science podcast, Science Brunch. Her first book, What's in Your Genes?, is a conversational overview of genetics. You can find her work at beatricebiologist.com.

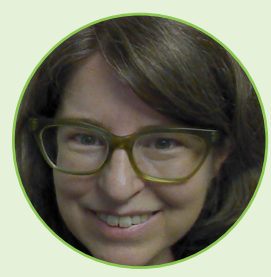

\section{ANN E. STAPLETON}

Ann E. Stapleton's research is focused on experimental testing of genotype-environmentphenotype models and systems modeling, and she has more than 10 years experience in development of cyberinfrastructure for biology. She has published in genetics, plant biology, computer science, and statistics journals. She served as Chair of the 2017 Gordon Research Conference on Quantitative Genetics and Genomics and as the faculty lead to coordinate and design a new interdisciplinary professional science master's program in data science at UNCW. *stapletona@uncw.edu 